\title{
Comparative Study on Sir Thomas More \& Hakim Abolqasem Ferdowsi, in Subject \& Utopia
}

\author{
Hamid Reza Kasikhan ${ }^{1}$ \\ ${ }^{1}$ Islamic Azad University, Yadegar-e-Imam Khomeini (RAH), Shahr-e-Rey Branch, Tehran, Iran \\ Correspondence: Hamid Reza Kasikhan, Assistant Professor in English Literature and Head of English \\ Language Department, Faculty of Humanities, Islamic Azad University, Yadegar-e-Imam Khomeini (RAH), \\ Shahr-e-Rey Branch, Tehran, Iran.
}

Received: July 2, 2018 Accepted: August 13, 2018 Online Published: August 22, 2018

doi:10.5539/ells.v8n3p45 URL: https://doi.org/10.5539/ells.v8n3p45

\begin{abstract}
The present study compares two poets and scholars (English and Persian) in terms of subject and utopia. Sir Thomas More's Merry Jest is compared with one piece of Ferdowsi's Shahnameh in terms of the common subject or message they convey in classification of people's occupations. Having a civilized and more disciplined society, both poets believed in classifying people based on their skills, competence and efficiencies; and insisted that each group should remain in their own category and avoid interfering or entering the profession of which they know nothing. Moreover, as social scholars, both put forward the theory of utopia and describe the ideal society in which people can live more comfortably and pleasantly. Living in the $16^{\text {th }}$ century, the principles proposed by More for his utopia basically turn round modern social interactions and attempts to recognize the reason of problems at the first step, and then amending them through the laws he suggests. In Ferdowsi's utopia, however, the ideal society is based on two distinct factors: physical structure of towns, the number of necessary architectural buildings constructed, and the moral enhancement of its residents in holding high human values as honesty, integrity and knowledge. The present research aims to probe, examine and find answers for two main questions: what affinities and dichotomies are there in "job classification" and the concept of "utopia" held by Ferdowsi \& More? The research method is library-based and the obtained results are categorized by descriptive-analytic method.
\end{abstract}

Keywords: architectural elements, Ferdowsi, lack of corruption, Merry Jest, Utopia, Sir Thomas More

\section{Introduction}

\subsection{General Definition}

Utopia is defined as an imaginary or hypothetical place or state of things considered to be perfect; a condition of ideal perfection. In the rare or obsolete sense, it refers to an imaginary distant region or country. Nowadays, it may be used in political, economic and social debate to ridicule an impossibly ideal scheme, especially for social improvement. It is derived from Greek language (ou-topos) written "eutopia" and translated to "nowhere land" in Persian by Shahabeddin Sohrevardi (1154-1191), Persian philosopher and founder of the Iranian school of Illumination.

\subsection{Historical Background}

The term was used by Sir Thomas More (1478 -1535), English lawyer, social philosopher, author, statesman, and noted Renaissance humanist, to describe a perfect political system. The term gradually exceeded the bounds of sociopolitical debates and now reflects a flawless, desired and unattainable reality originally and primarily adduced in Plato's The Republic in which he explored the nature and structure of a justice-centered society. He proposed a political system based on the division of the population into three classes, determined by education rather than birth or wealth: rulers, police, armed forces, and civilians.

\subsubsection{Concept of Utopia in Greece}

In Greek philosophical thought, justice is the society's spirit, followed by three other virtues: wisdom, courage, and self-restraint. In Plato's viewpoint, justice surpasses and exceeds three other virtues, because a righteous man is potentially capable to extend justice and to judge fairly. Justice provides harmony among different layers of a society and can efficiently create overt and covert peace among people. 


\subsubsection{Concept of Utopia in Iran}

Since ancient time, the term had been the obsession and discussion of many Iranian philosophers too. In religious and mythological texts, the term is debated widely reflecting the ideal thought of various Persian commentators such as, Al-Farabi (872-951), Abu Ali Sina (980-1037), Nasir al-Din Tusi (1201-1274) to secure perfection and redemption. In utopian society of Farabi, man's highest virtue is his prosperity or happiness merely achievable in civic societies requiring social cooperation. Man's demand is miscellaneous, numerous and cannot meet all his/her needs alone. Man can accomplish his/her desires through fair and wise division of social responsibilities. All three aforementioned philosophers firmly believed in each man's unique genius, talent and nature. They maintain that utopia appears when man assumes the social responsibility matching his or her talent and nature, and when all social and political hierarchal status gets formed based on individual's eligibility and qualifications. To most Persian philosophers, the main purpose of utopia is man's prosperity or happiness regarded as absolute goodness. To Farabi, man's prosperity does not merely belong to the earthly world, but it includes the heavenly world as well, guarantying man's redemption. He maintains that the final aim of man's creation is attaining prosperity, but the initial step is to recognize what prosperity is.

\subsubsection{Utopia from Karl Mannheim's Viewpoint}

In the twentieth century, due to fundamental social, economic and political reform, the concept of utopia was gradually enriched and refined by western philosophers. Karl Mannheim (1893-1947), Hungarian-born sociologist, who is well-reputed for his book Ideology and Utopia (1929), asserts that to achieve utopia, knowing and understanding ideologies is of great significance, because ideologies form the true nature of any society and can influence theories of philosophy and even history. To him, ideology is connected to the notion of reality, while culture focuses on the mind and mentality of the individuals to perceive that reality. He believed that the term ideology needs to be broadened as they may sometimes obscure the facts. He insisted that people and the public are significant in preserving a democratic society, so dictating only one ideology is a potential threat to democracy.

\subsubsection{Utopia from Ernst Bloch's Viewpoint}

Other western commentators as Ernst Bloch (1885-1977), German Marxist philosopher, who was influenced by Karl Marx, believed that in a quite humanitarian condition, where oppression and exploitation no longer exist, a true revolutionary power threatens the peace of the society. He states that various kinds of utopias have been constructed and better lives dreamed by people in all cultures throughout history. Poetry, music, drama, painting ...etc can be regarded as the artistic manifestation of utopian dreams. Utopian impetus can be traced from children's fairy-tales, legends and dreams to scientific fields of medicine and architecture, however, the highest form of utopia is one that results in the termination of human suffering. To Bloch, expecting the absolute perfection is regarded as positive utopia not restricted to the organization of society. It should embrace nature too; otherwise, it will be degraded to abstraction. He maintains that most attempts toward creating utopia in the past were revolutionary, reflecting man's desire for perfection. He foresees two possible outcomes in history: absolute annihilation or absolute perfection.

\subsubsection{Utopia from Karl Raimund Popper's Viewpoint}

Sir Karl Raimund Popper (1902-1994), Austrian-British philosopher, seems to be more pragmatist in definition of utopia and the principles he proposes to attain the favorable society. He emphasizes on removing and eliminating concrete evils rather than realizing abstract goodness. Man's happiness can be established much easier by eliminating concrete miseries, rather than using political means. For instance, to eliminate poverty, one should use direct means and does it practically: assuring that all individuals have a minimum living income. To fight disease and illness, one should do it by constructing hospitals and building schools of medicine. Fighting crimes and criminality begins with fighting illiteracy. In each fighting battle, one should use direct means and begins with the most urgent evil in the society. It is also essential to make people sure and convinced that man can get rid of all these torments, evils and discomforts. He is an ardent advocate of liberal democracy in political discourse and believes that principles of social criticism pave the way to the flourishing of open society. He never bounded himself to one specific political idea, but embraced all various democratic political ideologies and attempted to reconcile, unite and harmonize them.

\subsection{The Aim of This Research}

In this paper, the concept of utopia is defined, discussed and analyzed from the viewpoint of two main scholars, poets and social thinkers: Sir Thomas More, English scholar and statesman, and Ferdowsi (940-1020), Persian poet and the composer of Shahnameh. 


\subsection{Clarification on the Term "Subject"}

Another concept discussed in this article is the term "subject" that the meaning of which is not far-fetched or difficult to perceive. In this paper, the term "subject" refers to the matter, message, theme, topic of discussion, consideration, or investigation. Thomas More and Ferdowsi share a common point in dealing with the subject of "jobs classification". Both scholars enumerate various jobs prevalent at their times, and assign particular group or class of people who best fit and match that job. Finally, both conclude that if men choose the job or profession they know best, that would be more beneficial for them and for their society. Concerning the first notion (job classification), it should be noted that the researcher failed to find any article, document, book or report to use in the present analysis and interpretation. In fact, the researcher came across the point quite coincidentally and accidentally through his personal studies. However, concerning the second point (utopia), the researcher can refer to the books listed in the references as well as certain articles studied haphazardly in previous years. Having studied the theories of eastern and western philosophers whose names mentioned in the introduction helped the researcher follow the developmental process of utopia in the passage of time: how the notion of utopia was formed, evolved and perfected.

\section{Method}

The research is mainly library-based and the results and findings are categorized in descriptive-analytic method. The vision and theories of the above-mentioned poets in two particular cases, namely the message of a poem and their presumptions on the notion of utopia, are compared, contrasted, and described.

\section{Results (I)}

\subsection{Data Analysis (The Subject of Job Classification)}

\subsubsection{Sir Thomas More's Merry Jest}

Sir Thomas More is an English scholar, statesman and Lord Chancellor (1529-32). From the time of the accession of Henry VIII (1509), More held a series of public offices, but was forced to resign as Lord Chancellor when he opposed the king's divorce from Catherine of Aragon. He was imprisoned in 1534 after refusing to take the oath on the Act of Succession, sanctioning Henry's marriage to Anne Boleyn. As the result of opposing the Act of Supremacy in the same year, More was beheaded. He is regarded as one of the leading humanists of the Renaissance and owed his reputation largely to his Utopia (1516), describing an ideal city-state.

One of More's well-known poems is Merry Jest. Here, he points out that everyone should stick on the job and profession he or she knows best, and that he or she should avoid trying other occupations they know nothing about. For instance, he implicitly states that how ludicrous and absurd it would be for a serjeant to act as a friar. Definitely, by the word "serjeant", he addresses a particular social class, namely "military men"; and by "friar", he means another class of society, namely "men of religion" or "clerics". He begins by stating that

\section{How a Serjeant would learn to play the Friar \\ Wise men alway, \\ Affirm and say, \\ That best tis for a man, \\ Diligently, \\ For to apply \\ The business that he can; \\ And in no wise \\ Toenterprise \\ Another faculty, \\ For he that will \\ And can no skill \\ Is never like to theeh.}

In two opening stanzas, Thomas More draws our attention to this point that anyone's success in any affair, especially business, depends on his or her skill in that field. Then he maintains by providing some examples. He continues

$$
\begin{gathered}
\text { A black draper* } \\
\text { With white paper, }
\end{gathered}
$$

To go to writing school, 


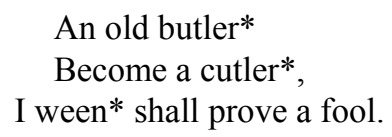

[draper: dealer in cloth]

[butler: a principal manservant, in charge of wine for the royal table]

[cutler: a person who makes, deals in, or repairs knives, forks, and similar utensils]

[ween: think, surmise, or suppose]

To More, one who shifts or changes the field of his or her craftsmanship proves to be fool and idiot, as he or she has little or no experience in that field. Another example he adduces is that of a lawyer who changes his occupation and tries to be a merchant. Here, More satirically mocks and pokes fun of him and ridiculously asks God to make him sane:

$$
\begin{gathered}
\text { A man of law, } \\
\text { That never saw } \\
\text { The ways to buy and sell, } \\
\text { Weening to rise } \\
\text { By merchandise, } \\
\text { I pray God speed him well. }
\end{gathered}
$$

Then he provides two more examples: a hat maker or hat dealer who audaciously enters philosophy and attempts to discuss philosophical issues of which he knows nothing. Similarly, a salesman who erroneously interferes in theological debate:

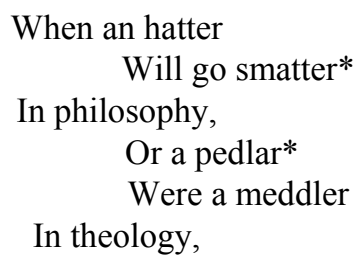

[smatter: superficial knowledge]

[pedlar: a person who carries small goods for sale]

It seems that the whole poem and particularly this stanza refers to his conflict with Martin Luther, German protestant theologian, who preached the doctrine of justification by faith rather than by works. Luther bases the notion of salvation on faith only, rejects most of Catholic rituals and ceremonies, and strongly opposes the extremes made by the Catholic Church.

More's poem lit the fire of intense verbal argument with Martin Luther followed by insult and insolence through the letters exchanged between them. This confrontation with Luther obsessed Thomas More with this significant point that not anybody is eligible or qualified to enter any field he or she wishes. The poem also implies More's dissatisfaction to Henry VIII's decision in declaring himself superior to church and firmly refused to take the oath of supremacy. In other words, to him, king should run the political affairs of the country and that he should let the religious affairs of Catholicism be decided by Pope and the Church authorities. Neither side should intervene in something on which they have no knowledge, and are therefore, incompetent to express their ideas about.

\subsubsection{Hakim Abolqasem Ferdowsi's Shahnameh}

Hakim Abolqasem Ferdowsi Tusi (935-1025), is one of the well-known revered Persian poets who composed Shahnameh, meaning the "Book of Kings" in Persian. It is the world's longest epic poem exceeding 60000 lines. It is considered as the national epic of Iran and all Persian-speaking countries such as Afghanistan and Tajikistan. He succeeds to accomplish drafting Shahnameh under patronage of the Samanid and the Ghaznavid dynasties. He was deeply encouraged by the Samanid princes to work and devote his life on this book. Samanid rulers provided the ground to revive Persian culture, literature and traditions after the Arab conquest in the seventh century. This dynasty was unfortunately conquered by the Ghaznavid Turks that unlike the previous rulers, had no interest in Ferdowsi and his lifework. He died about $1020 \mathrm{CE}$ in poverty and hardship. Although he was embittered by royal neglect, he was quite confident that his 60000 line poem will find greatest universal fame in future. Referring back to the tenth and early eleventh century of Persian literature, one finds out that the same subject of distinction of jobs and the necessity of dividing professions is ardently and adeptly narrated by Ferdowsi. 
In the introduction of Shahnameh, he explains how Jamshid, the Iranian king, divides men into four groups and assigns the members of each group with quite separate responsibilities. Jamshid who is described as having been the fourth and greatest king of the epigraphically unattested Pishdadian dynasty (before Kavanian dynesty) believed that the affairs of the country will not go on smoothly unless each group knows and does his own responsibility. It is emphasized that members of each group should avoid meddling or getting involved in something irrelevant to them. It is said that it took fifty years for Jamshid to classify men into different groups. The following excerpts are derived from Shahnameh (1994), lines 400-416 followed by their translations:

$$
\begin{aligned}
& \text { بدين اندرون نيز ينجاه خورد } \\
& \text { ز هر انجمن ييشه وركرد كرد }
\end{aligned}
$$

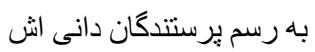

$$
\begin{aligned}
& \text { كرو هى كه كانوزيان خو انى اش لش }
\end{aligned}
$$

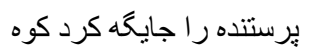

$$
\begin{aligned}
& \text { جدا كردشان از ميان كروه كرون } \\
& \text { نوان، يِي روشن جهاندارشان }
\end{aligned}
$$

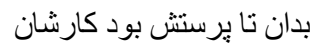

Then, he recounts and enumerates each group one by one as follows that took about fifty years long,

He specifies the first group as the clerics and separates them from the others. He sent them to the mountains to continue worshiping God

$$
\begin{aligned}
& \text { همى نام نيساريان خو اندند } \\
& \text { فروزنده لشكر و كثورند } \\
& \text { صفى بر دكر دست بنشاندند } \\
& \text { كجا شير مردان جنحاورند } \\
& \text { وز ايشان بود نام مردى به بِاى كُون } \\
& \text { كز ايثان بود تخت شاهى به جاى جنائ }
\end{aligned}
$$

He enumerates the second group as the military men, fighters, soldiers, warriors who are engaged in warfare. He praises them as the group defending the country, people and kingdom.

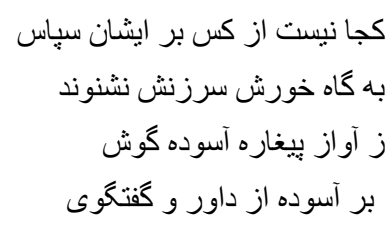

$$
\begin{aligned}
& \text { بسودى سه ديكر كره ر ا شناس } \\
& \text { بكارند و ورزند و خود بدروند }
\end{aligned}
$$

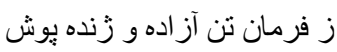

$$
\begin{aligned}
& \text { تن آز اد و آباد كينى بروى آده ترني }
\end{aligned}
$$

He itemizes the third group as the peasants and farmers whose productive role in the country is admirable, valuable and praiseworthy to all. They produce food and raise cattle on farms and pastures. They have an independent life and consequently, never stretch their hands before others for help. They stand on their own feet and enjoy an honorable life.

$$
\text { روان دمان هميثه ورزان ابداسركشى بودي }
$$

$$
\text { كهار كارشان هو هوخنان اهيشه بوشى }
$$

Craftsmen are the fourth group denominated in Shahnameh. Their main obsession and preoccupation is work only, and enjoy being engaged in practicing a handicraft. Joblessness and unemployment is quite meaningless to them and their lives depend on being involved in cultivating a branch of art.

$$
\begin{aligned}
& \text { بخورد و بورزيد و بخشيد جِيز } \\
& \text { سزاو ار بكزيد و بنمود راه } \\
& \text { بييند بداند كم و بيش را را }
\end{aligned}
$$

$$
\begin{aligned}
& \text { بدين اندرون سال بنجاه نيز } \\
& \text { از اين هر يكى را بكى بإيحاه }
\end{aligned}
$$

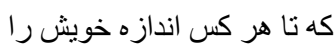

It took fifty years for Jamshid to classify and fix each group in their own positions, based on their capabilities and potentials. Finally, everybody was pleased in being given the responsibility he knew well. (Ferdowsi, 1994, lines 400-416)

The comparison of these two works (Thomas More's Merry Jest \& Ferdowsi's Shahnameh) signifies that some subject matters, regardless of era or period, can be the mental preoccupation of authors and poets. Literature has always conveyed common social issues and functioned as a mirror in reflecting common public problems and the ways such disputes get solved.

\section{Discussion (I)}

\subsection{Comparison and Contrast of Two Scholars in Terms of "Subject" (Message)}

Both poets and scholars shared the same topic in their poems: "classification of jobs" that is definitely one of the rarest and most unusual topics a poet may compose poem for. Most poets mainly write on general and universal concepts as love, war, death, birth, nature, youth, old age ... etc. Therefore, it seems quite uncommon and exceptional to write on a subject that is of readers' least interest. Few people regard jobs' classification as 
important to write a poem about. So, this question may be raised that what made these two poets write on such a subject. In the case of Thomas More, it should be stated that the nature and concept of "job classification" was not the prime concern of More. He used it metaphorically to satirize and deride his religious rival, Martin Luther. He composed the Merry Jest to indirectly convince Luther not to interfere in the affairs he knows nothing about. Meanwhile, he was implicitly criticizing Henry VIII (1491-1547) who was intended to change the laws of the church regarding divorce. So, the subject matter or message of More's Merry Jest although seems to be about classification of job at surface structure, it expresses his sharp criticism and sarcastic disapproval to what Martin Luther and Henry XIII did in Germany and England.

In contrast, Ferdowsi's main intent to write about jobs classification as subject or message, was neither criticizing nor deriding anyone. Quite opposite, he intended to reinforce and encourage the national morale and sows the seeds of optimism among people emphasizing that national affairs would go on smoothly and easily if individual citizens select the job and profession they know well. He enumerates different common jobs of his time (farmers, warriors, craftsmen, clergymen ... etc) to discipline the social structure, because he believed the more regulated the social framework, the better and more organized the economic and social status would be. Consequently, in such desirable circumstances, kings can also enjoy a robust political system ensuring people's security and protecting their territories from any possible danger or threat.

\section{Results (II)}

\subsection{Data Analysis (The Concept of Utopia)}

\subsubsection{Sir Thomas More's Utopia}

Having considered the social life of English people in the $16^{\text {th }}$ century and various political and social problems they faced, More begins explaining his utopia. Highland (1942) appreciates the idea of utopia not merely for the model world they present, but rather they activate and prompt man's mind to constantly evaluate the existing society, criticize it and suggest better alternatives for the problems they come across. He believed that man fails to reform and improve society through enacting good laws, as laws alone are insufficient to remove social problems. The development and progress of a society, he believed, depends on investigating the origin and source of the issues: why some people steal, for instance. To clarify his ideas, he composed a book entitled Utopia (1516) and explicated his thoughts through an imaginary and fictional story of someone who gets lost in the sea and finally reaches an island the inhabitants of which live in ease, affluence and prosperity. They worked just six hours per day and saved their products in store to use it at the time of need.

According to the laws of the island, there was no private ownership and that the possession of everything was at the control of the government. More (2016) believed that people fail to have a happy life as long as money is considered the standard criteria for other things. People's property should be controlled, managed or directed by the government. Imbalance in society, he viewed, is due to private ownership that potentially results in social confusion, disorder and disturbance. Therefore, he believed in removing or at least confining private ownership to avoid such irregularity and non-uniformity. Money should be centralized in government to be used for domestic and international affairs, and therefore, people had no money at all. Simply stating, reform in a society, according to More, is not caused by enacting good laws, but by finding out the reasons of the problems.

State authorities were elected by people: every ten families elected a representative. Among each ten representative someone was selected called phylarch ... and this process continued and narrowed down to four people. Among those four magistrates, people chose one as their king as long as he does not violate the laws, of course.

In More's utopic society, populous families had to deliver some of their children to childless families to be trained appropriately. In the section entitled Of Their Traffic, More (2016) specifies and sets out the minimum and maximum number of children a family is allowed to have. Although he never mentions a fixed number for the children, he recommends minimum ten and maximum sixteen as the ideal number of children. To keep the balance, he proposes that populous families are advised to give some of their children to those that do not abound so much.

More's idea was influential in the formation of new thoughts and instigated the rise of some movements, as Peasants' Movement in Germany. In Italy, Tommaso Campanella (1568-1639), was one of the philosophers, theologian, astrologer and poet who was deeply motivated by More's idea and prompted him to write a book entitled The City of the Sun. In his book that is almost a copy of More's utopia, he proposes that the wisest man should be the ruler, and that his decrees need being fulfilled and obeyed by three secretaries: defense secretary (power), secretary of social affairs and family (love), secretary of education (wisdom). Although church charged 
him to blasphemy, his thoughts and ideas left tremendous effect on Englishmen.

More's idea regarding the utopic society was discussed by many critics. His ideas, critics believe, are based on limited number of island inhabitants and are therefore, far from the realities of the world we live in today. Economically speaking, in developed societies, six hours work is not sufficient to accomplish the needs of a community, and men have to work much longer and harder. The kind of sovereignty proposed by More is reminiscent of royal monarchy in which the king or the queen rules forever; whereas, nowadays this kind of ruling is not much common or popular worldwide, and conversely, many people consider it as a kind of tyranny in which people's rights can be easily violated.

The third point under scrutiny of critics was that More never believed in enacting good laws for the enhancement and reform of the society; whereas, nowadays law is considered as one of the most significant facts in almost all societies without which there would be chaos and anarchy.

He abolished private ownership and delivered the possession of people's assets to government. In reality, if this occurs today, people will be dissuaded from work and prefer to have rest. Depriving people from their own properties reduces or even stops the speed of economic affairs, products and business interaction that can potentially lead to decadence, decline and deterioration of any society.

Finally, More's insistence on mind and wisdom made him away from divine ideas and his utopia is therefore, devoid of religious values. Populous families, according to More, had to deliver some of their children to childless families. This may deprive children from being reared properly under their own real parents and this may prompt them to commit illegal acts, crimes, and other forms of misconduct due to inappropriate upbringing.

\subsubsection{Ferdowsi's Utopia}

The utopic society that Ferdowsi had in mind can be traced in two different ways: on one side, it is focused on physical structure, as architecture and urban development and the effective role those architectural buildings had on people's life and their social interactions; and on the other side, it emphasizes on the moral framework, highlighting the perfection and flawlessness of the society in terms of morality and lack of corruption. Certain issues as the kind of government, working hours, problem of childless families, lack of good social laws ...etc. were not Ferdowsi's main and prime concerns, in fact, he insisted on lack of evil or iniquity in his ideal society. His epic book, Shahnameh, not only provides one with miscellaneous heroic and mythological wars, but also presents common religious and social customs or traditions, people's hierarchy in terms of social affairs, as well as the social and political atmosphere prevalent in Iranian cities many centuries before Sir Thomas More.

\section{A. Physical Structure (Architectural Elements)}

Having studied the typical architectural elements of the time, as dome, porch, fortress, fireplace, chamber, vault ...etc., one can attain more detailed information on people's ideal lifestyle and the ideal community of Ferdowsi about ten centuries ago.

(a) Porch

Porch is considered as one of important architectural elements in Iranian building construction. The use of porch dates back to the ancient time and it had a wide-range of use in architectural design such as, schools, gardens, mosques, palaces, caravanserai, graves ...etc. In different parts of Shahnameh Ferdowsi refers to porch and emulates it with tall palaces:

$$
\text { كنون }
$$

Now, I shall renew (begin) my speech by talking about Khosrow's Madaen,

Somebody saw a magnificent arc and porch that nobody had seen or heard before,

On one side of the porch, he saw an arc that was too high to be seen. (Ferdowsi, 1994, lines 1481-82)

(b) Dome

Dome is a rounded vault forming the roof of a building, and has an elliptical or polygonal base. After Islam, dome became a distinctive feature in Iranian architecture, especially in mosques and other religious building. In the construction of most palaces and mansions, as Sarvestan palace, Damghan palace, Sassanid fireplaces and Khosrow's mansion, dome plays an important role linking other parts of a building as porches and courtyards together. Ferdowsi refers to this architectural element in different parts of his Shahnameh: 


$$
\begin{aligned}
& \text { جهان شد جو ديبا بهز زر آزده } \\
& \text { همه ر راه و بى ر اه كنبد زده } \\
& \text { ز كنبد به سر ها فرو ريختند } \\
& \text { همه مشك با كو هر آميختند }
\end{aligned}
$$

In every place, dome is constructed, the world is decorated with gold and looked like a piece of colorful cloth of silk,

Pleasant smelling materials and various jewelries were hanged from domes. (Ferdowsi, 1994, lines 2257-58)

\section{(c) Square}

In Ferdowsi's ideal society, a perfect town should have various squares used for different purposes: assembly of people, business interactions and economic exchange, holding sport games and other public recreational events, performing military marches, notification and public announcements, punishment of criminals and lawbreakers ... etc. Ferdowsi narrates sport events of mallet, played with a long-handled implement like a hammer used for striking the balls, between Iranian and Toranian held in squares near King's palace:

$$
\text { كه با كوى و جو گًان به ميدان شويم }
$$

We enter the square holding ball and stick; sometimes we attack and are happy,

Siavash told him we are at the service of your decree; all horse-riders, square and mallet are at your control and command. (Ferdowsi, 1994, lines 153-4)

$$
\begin{aligned}
& \text { زياليز و ازكلشن ارجمند } \\
& \text { از ايو ان وميدان وكاخ بلند } \\
& \text { به هامون كل وسنبل و لاله كثت الت ارجن }
\end{aligned}
$$

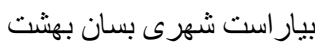

By (constructing) porches, squares, tall palaces, and (by breeding) gardens and splendid orchards,

He ornamented the town as paradise and planted flowers, hyacinth and tulips in pastures. (Ferdowsi, 1994, lines 12075-76)

\section{(d) Fortress}

Definitely, the ideal society in ten centuries ago would not have been completed without tall, tough and impenetrable fortresses. They were needed to keep the towns safe, secure and protected both from the enemies' invasion and from the natural storms and damages. They were not merely constructed for military purposes, but big towns were usually built inside them to maximize the level of residents' safety:

$$
\begin{aligned}
& \text { در دز يديد آمد از جايگاه }
\end{aligned}
$$

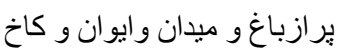

$$
\begin{aligned}
& \text { برفتند ديوان به فرمان شاه } \\
& \text { يكى شهر ديد اندر آن دز فر اخ برن بـان }
\end{aligned}
$$

All monsters left by the King's command; the door of the fortress appeared from its place,

One saw a large town inside the fortress; filled with gardens, squares, porches and palaces.

(Ferdowsi, 1994, lines 1781-82)

\section{B. Moral Structure (Lack of Corruption)}

Being annoyed for the invasion of Arabs and different kinds of social, economic, political and religious problems Iranian had to encounter, Ferdowsi's main solution was returning to past and reviving Iranian mythological identity. Through such retrospective-oriented outlook, he succeeded to restore Iranians' identity, their common spirit, as well as their firm and united resolution. Basically, myth and epic belongs to people who have gained collective spirit and have formed a unified nation sharing the same identity, problems and happiness. Through various stories narrated in Shahnameh, Ferdowsi attempted to keep the morality of people refined, pure, natural and genuine from any kinds of flaw, vice and immoralities. An unhealthy society, he insisted, paves the way for the deterioration of all human values. The most destructive anti-value introduced in Iranian national epic is greed and avarice. This may seem paradoxical, because epic usually centers round assault or attack, invading a country or territory with armed forces, followed by occupation, slaughter, massacre, destruction ... etc. In most wars and armed confrontations, the king is determined to extend and expand his territory, enslaving more people, looting and plundering their wealth, taking their women and girls to his harem and increasing the number of his wives. Ferdowsi's moral preaching explicitly condemns man's insatiable desire to greed and avarice and introduces these two features as the most destructive elements, because they lead to war, bloodshed and murder. Ferdowsi believed that avarice is in contrast to wisdom and sagacity. It generates war and sows the seeds of hostility, grudge and resentment. Greedy men are doomed to bad reputation, and for Ferdowsi, ill reputation is man's real death. 
Therefore, in ideal society presented by Ferdowsi, infamy or scandalous reputation has no place at all. In fact, honesty, integrity and knowledge are essential requirements for people living in Ferdowsi's utopia:

$$
\begin{aligned}
& \text { بد و نيك روزى سر آيد همى } \\
& \text { شود كار كيتيت يكسر دراز } \\
& \text { به كيتى ز كس نشنود آفرين }
\end{aligned}
$$

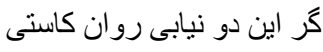

$$
\begin{aligned}
& \text { كه از آز كاهد همى آبروى }
\end{aligned}
$$

$$
\begin{aligned}
& \text { جهان جون به زارى برآيد همى } \\
& \text { جو بسنى كمر بر در راه آز آز } \\
& \text { يرستنده آز و جوياى كين } \\
& \text { در دانش و آنخهى راستى جري } \\
& \text { بخور آنجه دارى و بيشى مجوى النى }
\end{aligned}
$$

Since the world will come to an end one day; good and bad deeds will be terminated one day too,

Your life will be complicated and intricate, because you are determined to be greedy;

One who follows greed, avarice and hostility; will not be admired or appreciated by anyone,

If one fails to access knowledge, honesty and integrity; he or she will suffer from disgrace,

Be contended to what you already have and avoid greed; as greed results in disgrace.

(Ferdowsi, 1994, lines 651-655)

\section{Discussion (II)}

\subsection{Comparison and Contrast of Two Scholars in Terms of "Utopia"}

The two scholars had different criteria and opinions on the concept of "utopia" as they lived in two different ages. Ferdowsi lived 500 years earlier than Thomas More, when the pillars of society, social structure and political system were completely different from those at the time of More. At Ferdowsi's time, there was only limited number of recognized jobs. Laws had not been drafted formally as they have been today, and the concept of nation-state had not been developed yet. A king's territory was not fixed or stable; it could be extended or narrowed in wars. People were not any threat for kings, nor were there any potential danger from the army men or from the high-ranking commanders for kings. Kings were regarded as God's successors and there were mutual kindness between them and their subjects. Kings could count on the solidarity and unification of their subjects in defending and protecting the monarchy. To excel the neighboring empires in social and military development, kings usually ordered the construction of unique architectural buildings pursuing two different aims: defense and vitality. Buildings as castles, fortresses, strongholds ... etc were constructed with defensive purposes; and meanwhile, buildings as dome, porch, terrace, square ... etc were constructed with life-giving aims. So, from Ferdowsi's viewpoint, a utopian society should embody both aspects of development: social and military. Moreover, Ferdowsi took another aspect of development into serious consideration: individual integrity. In fact, men's uplifting their spirits, refinement of morality, avoiding greed and corruption, heightening one's level of knowledge, living honestly and decently were his prime concerns. To him, making a utopian society is not feasible unless the residents of that community attempt to improve and cultivate the ethics and principles of decent morality in themselves.

In contrast, people's modest behavior or their dignified conduct in social environment was not More's prime concern. He was intended to regulate and control people's actions by deterring laws and make them act within a formal, recognized and law-oriented framework. People could disregard behaving uprightly, honestly or respectably as long as they obey laws and respecting the norms of the community. Unlike Ferdowsi, he deliberately interfered in determining and assigning eligible people to deliver power to, regulating the process of election, and deciding the duties of the authorities. Actually, at Ferdowsi's era, kingdom or monarchy was the only form of power imaginable. Kings were considered as Gods whose words and decrees were the final decisions. They normally inherited power from their fathers as long as they were not overthrown by another king. Delegation of power to a limited number of people underwent more democratic procedure at the age of Thomas More, and people were allowed to play some role in the election of authorities. In the utopian society dreamed by More, private ownership was banned and the central government assumed the responsibility of dividing wealth and peace equally. He even interfered in more details of family issues and recommended the exchange of children between more and less populous families. Whereas, Ferdowsi never involved in such cases and instead, he paid more attention to some general ethics and positive moral features, as elevating one's knowledge, acquiring integrity and avoiding avarice, because he believed a utopian society would not be realized or fulfilled unless the residents of that community enjoy human qualities. To Ferdowsi, having had morality-abiding inhabitants is one of, if not all, conditions of attaining real utopia. 


\section{Conclusion}

Despite the long time interval between Ferdowsi and Sir Thomas More, one can detect some kinds of affinities in the works and ideas of these two poets and scholars. Both had close connection to the royal family and shared the same concern in classification of people based on their abilities. Although the job categories they present rise from two different grounds and motivation, their categories look identical and provide evidences for both poets' concern that there should be a logical correspondence between one's occupation and his/her real ability. As wise, learned and enlightened men of their time, both scholars proposed the ideal society in which people can enjoy easier and happier life. Despite the fact that both scholars adduce utopia, the archetypal community they present are rooted in two different social atmospheres. More's utopia is partially based on new concepts and modern ideas, as rejecting private ownership, centralizing money by the government, delivering extra children to childless families, enacting good laws, investigating the reasons of social issues, ... etc; whereas, Ferdowsi's utopia is based on two essential points: first, physical structure of towns and cities, whether or not there are miscellaneous forms of architectural buildings, and secondly, the moral mentality of people, whether or not they retain honesty, wisdom and knowledge. It seems that today's modern world is strengthened by most of the theories and notions proposed by both thinkers. On one side, advanced societies are detected through the tall and modern buildings constructed for public needs, the necessary laws enacted by lawmakers, and on the other side, through the healthy, moral and decent human attributes held by people, and the ethical, refined and decorous social interaction they have with each other.

\section{References}

Aretoulakis, E. (2014). The Prefatory/Postscript Letters to St. Thomas More's Utopia: The Culture of "Seeing" as a Reality-Conferring Strategy. Journal of Early Modern Studies, 3, 91-113.

Elsky, S. (2013). Common Law and the Commonplace in Thomas More's Utopia. https://doi.org/10.1111/1475-6757.12006

Ferdowsi, A. (1994). Five stories from the Shahnameh. Tehran, Iran: Atelie Honar.

Ferdowsi, A., \& Zimmern, H. (2010). Epics of Kings: Hero tales of ancient Persia: Retold from Firdusi's Shahnameh. Maryland, Bethesda, USA: Ibex Publication.

Highland, H. J. (1942). Utopian education. A study of the ideal worlds from Sir Thomas More to H. G. Wells. New York, USA: New York University.

Keen, R. (2011). Between Utopia and Dystopia: Erasmus, Thomas More, and the Humanist Republic of Letters. Erasmus Studies, 31(1), 87-89. https://doi.org/10.1163/027628511X598088

Kessler, S. (2002). Religious Freedom in Thomas More's Utopia. The Review of Politics, 64(2), 207-230. https://doi.org/10.1017/S0034670500038079

Kinna, R. (2004). The relevance of Morris's utopia. The European Legacy, 9(6), 739-750. https://doi.org/10.1080/1084877042000311590

Lewis, F. (2015). The Shahnameh of Ferdowsi as World Literature. Iranian Studies, 48(3), 313-336. https://doi.org/10.1080/00210862.2015.1023063

More, S. T. (2016). Utopia. Retrieved from http://www.fullbooks.com/Utopia.html

Roper, W. (1980). Life of Sir Thomas More. Springfield, Illinois, USA: Templegate Pub.

Waley, M. I. (2007). Shahnama: The Visual Language of the Persian Book of Kings. Ed. by R. Hillenbrand. (VARIE Occasional Papers, 2.) Aldershot: Ashgate. 2004. The Library, 8(1), 71-72. https://doi.org/10.1093/library/8.1.71

\section{Copyrights}

Copyright for this article is retained by the author, with first publication rights granted to the journal.

This is an open-access article distributed under the terms and conditions of the Creative Commons Attribution license (http://creativecommons.org/licenses/by/4.0/). 